\title{
Weaving Womanhood into Warfare: Gender-Hybrid Narratives of Amazons Penthesilea and Diana Prince
}

\author{
Anne Lee ${ }^{1}$ and Bethany Stallings ${ }^{\#}$ \\ ${ }^{1}$ Yongsang International School of Seoul, Hannam-dong, Yongsan-gu, Seoul, South Korea \\ ${ }^{\#}$ Advisor
}

\section{$\underline{\text { ABSTRACT }}$}

Largely rooted in ancient Greek essentialism, Western dichotomies of masculinity and femininity have been historically used to divide the sexes and limit women's involvement in male institutions of power. The female warrior is an anomalous case. Fictional tropes of this type, especially the Amazons of Greek mythology, embody both masculine and feminine associations to exist in the separate spheres of womanhood and military heroism. Two transhistorical Amazons-Penthesilea (from Quintus Smyrnaeus' Posthomerica) and Diana Prince (from the 2017 film Wonder Woman) - were analyzed to explore the evolution of Western perceptions on powerful women in traditionally male spheres of influence. Guided by gender and classics theories, a thematic and narrative analysis focusing on the characters' gender hybridity (the combination of masculine and feminine distinctions) demonstrated new understandings: Penthesilea's story demonstrates that hybridity in antiquity reinforced the hegemonic implications of gender essentialism. Diana's modern hybridity empowers female success in male realms. Nonetheless, both narratives establish the difficulty of crossing gendered boundaries, as compromise and defeat accompany hybridity. Comparing ancient and modern adaptations of the Amazons reveals that while women's presence in masculine spheres remains tentative in Western society, reimagined female warriors represent increasing acceptance towards women adopting hybrid roles in public expressions of power.

"What do spectators in the theater gain from thinking, in the mode of fiction, things that in everyday life cannot and must not be thought?" 1

Nicole Loraux, Tragic Ways of Killing a Woman

"The traces of the past are always with us to shatter sharply drawn differentiations of period and of culture. If there was a complete gap between past ages and our own present, the past would probably seem merely unintelligible, uninteresting..."

Charles Martindale, "Redeeming the Text..."

\section{Introduction}

Modern Western imagination often continues the classical tradition. Embodying this trend is the DC Comics superheroine Wonder Woman, whose roots extend much further than her creation in the 1940s. She calls her tribe "the Amazons," mythical warrior women from ancient Greek mythology, whom her creator William Marston considered

\footnotetext{
${ }^{1}$ Nicole Loraux, Tragic Ways of Killing a Woman, trans. Anthony Forster (Cambridge: Harvard University Press, 1987), 64.

${ }^{2}$ Charles Martindale, "Redeeming the Text: The Validity of Comparisons of Classical and Postclassical Literature (A View from Britain)," Arion: A Journal of Humanities and the Classics 1, no. 3 (1991): 61, accessed October 25, 2020, https://www.jstor.org/stable/20163488.
} 
icons of female empowerment. His inspiration from the classical source demonstrates that depictions of ancient Amazons have contributed to modern discourse on women and power. Therefore, an analysis of Wonder Woman and her classical template of the Amazons offers insights into how Western notions of gender and their role in female access to power have shifted.

\section{Gender in ancient Greece}

Early Greek norms situate the Amazonian myth in the cultural context of the classical world. Under the essentialist theory of gender, the idea that "men and women represent opposite impulses" predominated classical Greek thought. ${ }^{3}$ Essentialism justified the segregation of gender roles between the sexes. For men, the polis (city) was their main duty. Spartan men, trained since childhood to be soldiers, were honored for their militaristic strength and courage. ${ }^{4}$ Democratic Athens encouraged mental and social skills such as politics in men. ${ }^{5}$ Meanwhile, the oikos (household) was the women's realm. Their primary roles were as wives, mothers, and weavers. ${ }^{6}$ As such, men occupied the public sphere, and women occupied the private.

Essentialism also informed the hegemonic beliefs of Greek patriarchy. The strict separation of spheres restricted female access to public realms of power. Aristotle claims in Politics: Patriarchy exists because women have "nothing which is by nature fitted to rule." 7 Greek lore also reinforced women's submissive position in society. Heroines and female villains exist in mythology, but most fall short to essentialist stereotypes. Like the archetypal Medea and Circe, they either express their power through "feminine" modes of sorcery and deceit or are punished for their undue dominance. ${ }^{8}$

\section{The Amazons}

The Greek myths of the Amazons challenged this essentialism. Unlike many powerful female characters in mythology, Amazon warriors do not gain an advantage over men through mystical or manipulative means. Instead, their customs and training are like those of "the warrior elite of Homeric epic." As daughters of Ares, the god of war, they excel in skills traditionally valued in men such as horse riding and military prowess. In fact, Homer thought of them as equals

\footnotetext{
${ }^{3}$ Scott Rubarth, "Competing Constructions of Masculinity in Ancient Greece," Athens Journal of Humanities \& Arts 1, no. 1 (2014): 30, accessed September 17, 2020, https:/www.atiner.gr/journals/humanities/2014-1-1-2RUBARTH.pdf. In fact, these "opposite impulses" so strongly dictated daily life and mandated acceptable behavior that effeminate characteristics were often used to insult men (much like how they are still used today). Essentialism also supports the idea that gender norms are tied to biology, further enforcing the idea of the separation of spheres. ${ }^{4}$ Ibid., 24.

${ }^{5}$ Ibid., 28.

${ }^{6}$ Elaine Fantham et al., Women in the Classical World: Image and Text (New York: Oxford University Press, 1994), 103. These social expectations to stay inside the home as mothers and weavers were mostly for high-class women. Some poorer women had to work outside of the home. Also, some women were allowed to participate in certain religious activities such as being priestesses. Nevertheless, occupying the oikos, child-bearing, child-rearing, and weaving were the roles of a paragon wife and the ideals that defined womanhood. The patron goddesses of these realms, Hestia, Artemis, Athena, and Hera, show the importance of such qualities in women.

${ }^{7}$ Fantham et al., 122. Contrasting ideas also existed in this time, as Plato's The Republic imagined a society in which upper class ("Guardian”) women had equal abilities and responsibilities as men, expressing a possibility of the arbitrary nature of gender roles. Ibid., 119-121.

${ }^{8}$ Ibid., 121-122

${ }^{9}$ Lorna Hardwick, “Ancient Amazons - Heroes, Outsiders or Women?” Greece \& Rome 37, no. 1 (1990): 23, accessed September 6, 2020, http://www.jstor.org/stable/643239.
} 
to men in fighting strength; the Iliad attaches titles such as antianerai (match for men) and epithets such as "who go to war like men" to these warriors. ${ }^{10}$

The Amazons are also noticeably "everything a [Greek] woman ought not to be." ${ }^{11}$ They define the norm by representing the antithesis of it. Through dialogue in The Histories, Herodotus contrasts the Amazons with traditional women: "We shoot the bow and throw the javelin and ride, but have never learned women's work; and your women do none of the things of which we speak, but stay in their wagons." ${ }^{12}$ Such deviation from essentialist gender roles is essential to the Amazons' legacy beyond the ancient context. The Amazons' blending of gender distinctions in adopting masculinity with female bodies continues to influence Western cultural studies. Their trope has been "continually reimagined to serve a changing culture and politics," especially for future feminist movements. ${ }^{13}$

\section{Wonder Woman}

A successor of the ancient Amazons is the superheroine Diana Prince, also known as "Wonder Woman." Feminism directly influenced William Marston, the original creator of Wonder Woman in the 1940s. ${ }^{14}$ Aiming to promote female empowerment, Marston took inspiration from the original Amazons' mixed gender associations and gave Wonder Woman both feminine and masculine strengths. She was introduced in 1941 to be "as lovely as Aphrodite, as wise as Athena, with the speed of Mercury, and the strength of Hercules." ${ }^{15}$ Cocca calls her norm-defying attributes an act of "hybridity." 16 This term reflects the general Amazon trend of blending essentialist determinants to create avenues of power. Before further exploring the Amazons' relationship to hybridity, however, the development of Western genderanalyzing frameworks needs to be examined for contextualization.

\section{Literature on Western Notions of Gender}

${ }^{10}$ Ibid., "Ancient Amazons," 15, 16. The feminine ending of - $a i$ "precludes any idea that this 'ethnic group' included men" and makes the group explicitly all women. Walter D. Penrose Jr., "The Unwanted Gaze? Feminism and the Reception of the Amazons in Wonder Woman," Journal EuGeStA 9, no. 9 (2019): 177, accessed October 3, 2020, https://eugesta-revue.univ-lille.fr/pdf/2019/7.Penrose_Eugesta_9_2019.pdf.

${ }^{11}$ P. Walcot, “Greek Attitudes towards Women: The Mythological Evidence," Greece \& Rome 31, no. 1 (1984): 42, accessed October 18, 2020. http://www.jstor.org/stable/642368.

${ }^{12}$ Herodotus, The Histories 4.114.3-4, ed. and trans. A.D. Godley, Loeb Classical Library (Cambridge: Harvard University Press, 1920).

${ }^{13}$ Fantham et al., 128. Penrose, 197. In the 20th century, the nickname "Amazon" was used to describe women who left to seek higher education or careers, feminists, suffragists, and women in the armed forces. Even earlier, depictions of medieval and Renaissance Amazon figures existed. Horse riding women were often compared to the Amazons.

${ }^{14}$ Penrose, 188. Marston was a first-wave feminist. First-wave feminism, which was prominent in the early 20 th century, is marked by its focus on legal issues such as suffrage and its tendency towards essentialist notions of gender. Straying from mainstream feminism of his time, Marston had radical views of feminine superiority. He claimed that the future will be under a matriarchy that will trump the self-destructive patriarchy with its gentler, loving qualities. ${ }^{15}$ Carolyn Cocca, "Negotiating the Third Wave of Feminism in 'Wonder Woman'," PS: Political Science and Politics 47, no. 1 (2014): 98, accessed September 6, 2020, http://www.jstor.org/stable/43284491. Wonder Woman's alternate name, "Diana," itself alludes to the Roman iteration of the goddess Artemis, who represents the gender dichotomies of masculine wilderness and hunt and feminine childbirth and virginity.

${ }^{16}$ Ibid. The term hybridity comes from postcolonial theory, which Darling-Wolf explicitly connects (see DarlingWolf, "Disturbingly Hybrid"). 
In the Western discourse on gender, the modern perspective both rejects and adheres to classical influences. In The Second Sex, Simone de Beauvoir claims that "one is not born, but, rather, becomes a woman." ${ }^{17}$ Unlike essentialists, de Beauvoir views biological sex as separate from gender. Her statement largely informs the feminist theory that womanhood is socially conditioned, or as eminent gender theorist Judith Butler states, "[a] historical situation rather than a natural fact." ${ }^{18}$ However, Butler qualifies de Beauvoir's argument by claiming that even outside of essentialism, gendered determinants are divisible. They "sustain discrete and binary categories [of masculine and feminine]." 19 Combining de Beauvoir's and Butler's views, answering the subproblem of what historically constitutes masculinity and femininity (in Western tradition) is necessitated.

\section{Traditional masculinity and femininity}

Echoing Greek essentialist practices, the public and private spheres of influence have been associated with dividing masculinity from femininity for centuries. ${ }^{20}$ Historian Emad examines this dichotomy in discussing Wonder Woman's tentative position in warfare, differentiating the "traditionally masculine, public realm of nationhood" from the "traditionally feminine, private realm." ${ }^{21}$ Emad's usage of these oppositional terms shows how the public/private theme remains relevant in modernity.

From the schism in spheres of influence, traditional expectations of masculine and feminine traits emerge. Because masculinity is associated with the public, outdoors, and war, it relates to traits such as physical strength, dominance, and aggression. Femininity, in contrast, is associated with passivity, subservience, and empathy. ${ }^{22}$ The media continues to spread these stereotypes in contemporary society. ${ }^{23}$ Even Marston adhered to these distinctions, acknowledging, "I have given Wonder Woman this [masculine] dominant force but have kept her loving, tender, maternal, and feminine in every other way." ${ }^{24}$

Another historical trend is the relegation of the feminine to a desired object of beauty. In Greek culture, erotic beauty was considered a "characteristically feminine mode of power." ${ }^{25}$ However, anxious ancient sources pushed hegemonic norms to overturn the perceived feminine control over the sexual. These norms were often enforced through patriarchal romance. For example, virginal girls were seen as needing to be tamed by sex and marriage. ${ }^{26}$ McCall extends this idea to contemporary fiction by coining the term "believable femininity," which requires female

${ }^{17}$ Judith Butler, "Performative Acts and Gender Constitution: An Essay in Phenomenology and Feminist Theory," Theatre Journal 40, no. 4 (1988): 519, accessed October 10, 2020, doi:10.2307/3207893.

18 Ibid., 520.

19 Ibid., 523.

${ }^{20}$ Rubarth, 24-26, 28-29. Fantham et al., 103.

${ }^{21}$ Italics added for emphasis. Mitra C. Emad, "Reading Wonder Woman's Body: Mythologies of Gender and Nation," The Journal of Popular Culture 39, no. 6 (2006): 955-956, accessed October 1, 2020, doi:10.1111/j.15405931.2006.00329.x.

22 The allocation of such traits are evidenced by social norms in ancient Greece. For example, an ideal Athenian woman was silent, invisible, and anonymous. In fact, the voice was thought to be an unnecessary tool for women to fulfil their roles as wife, mother, and weaver, so it was "strictly policed" and "central to the [female] virtue of... selfrestraint." Ruby Blondell, "The Problem of Female Beauty," in Helen of Troy: Beauty, Myth, Devastation, (N.p.: Oxford Scholarship Online, 2013), 22, doi:10.1093/acprof:oso/9780199731602.001.0001. On the other hand, wartime strength - physical and mental - was so important to men that the Greek word for "courage" (andreia) comes from the word for an adult male (anêr/andros). Fantham et al., 79; Rubarth, 24.

${ }^{23}$ See Julia T. Wood, “Gendered Media: The Influence of Media on Views of Gender," In Gendered Lives: Communication, Gender, and Culture (Belmont: Wadsworth Publishing, 1993), 32.

${ }^{24}$ Emad, "Reading Wonder Woman's Body," 982.

${ }^{25}$ Blondell, "The Problem of Female Beauty," 2. Although in Greek culture erotic beauty existed in both genders, while male beauty often reflected intellect and strength, feminine beauty was portrayed as especially "intrinsically erotic" because the female role of childbearing is directly "tied to the domain of sex and reproduction."

${ }^{26}$ Ibid., 5, 12 . 
characters to submit to hierarchical, heterosexual relationships or male desire to be accepted as satisfyingly feminine. ${ }^{27}$ Thus, romance and desirability are forced but essential attributes of femininity.

\section{Gender hybridity}

Binary oppositions in gender associations determine historically constituted divisions between masculinity and femininity without necessitating essentialism. However, in fictional female warriors, the mutually exclusive spheres of femininity and masculine warfare must coexist. A theoretical framework called "gender hybridity" bridges this gap. Compared to Cocca's general use of "hybridity" to describe Wonder Woman's mixed traits, Darling-Wolf specifies gender hybridity as the "broad set of acts, behaviors, and attitudes that... occupies both maleness and femaleness." 28 Gender hybridity allows interactions between masculinity and femininity within an individual where essentialism does not. Only such complex possibilities can allow for the paradoxical "female warrior."

The specific term "gender hybridity" is fairly new. Few papers systematically categorize a character's masculine and feminine dimensions to explore their explicit hybrid interactions. In The Experiences of Tiresias, Loraux uses binary gender oppositions to examine their blending in Heracles and other classical figures. ${ }^{29}$ However, Loraux discusses exclusively male cases. These are limited exchanges in which the man borrows the feminine and "gains in complexity" while the woman is left as an "elusive silhouette." ${ }^{30}$ How female characters navigate and blend gender binaries is not addressed; besides Cocca, studies of Amazon masculinity and femininity rarely use hybridity as a conceptual framework.

Another gap in this nascent area of inquiry is combining gender hybridity with classical reception. To address this research gap, I intend to analyze the interplay between gendered dimensions of two Amazons (one ancient and one modern) and the implications of these dimensions for their roles in the traditionally male realm of warfare. More specifically, I explore masculinity, femininity, and hybridity in Penthesilea from Quintus Smyrnaeus' Posthomerica and Diana Prince from the 2017 film Wonder Woman. Comparing gendered representations of Amazons across periods is significant because the extent to which modern adaptations challenge or maintain ancient narratives signals historical development. Furthermore, the politics of these fictionalized women are rooted in reality. Their depictions can inform us of broader Western perceptions of women with power in traditionally male spheres.

\section{Approach}

This study follows a thematic analysis paired with narrative analysis. Thematic and narrative analyses are often used together because a narrative analysis' purpose is to interpret the meaning of the qualitative data collected from thematic analysis. ${ }^{31} \mathrm{~A}$ thematic approach is essential for my goal of recognizing masculine and feminine patterns in the

\footnotetext{
${ }^{27}$ Jessica D. McCall, "Woman or Warrior? How Believable Femininity Shapes Warrior Women," (PhD diss., University of Nevada, Las Vegas, 2011, UNLV Theses, Dissertations, Professional Papers, and Capstones), $2,4$.

${ }^{28}$ Fabienne Darling-Wolf, "Disturbingly Hybrid or Distressingly Patriarchal? Gender Hybridity in a Global Environment," In Hybrid Identities: Theoretical and Empirical Examinations, Keri E. Iyall Smith and Patricia Leavy, ed, (Leiden: Brill, 2008), 66. The general concept of hybridity stems from postcolonial theory, as it allows for the meeting of previously exclusive and hegemonic dimensions (such as two cultures). Darling-Wolf applies this basic concept to the idea of gender hybridity, where the feminine and masculine dimensions meet.

${ }^{29}$ See Nicole Loraux, "Herakles: The Supermale and the Feminine," in The Experiences of Tiresias: The Feminine and the Greek Man, trans. Paula Wissing (Princeton: Princeton University Press, 1995).

${ }^{30}$ Ibid., 14-15.

${ }^{31}$ Samantha Andrews, "Thematic and Narrative Analysis in the Context of Courtroom Examinations With Alleged Victims of Child Abuse," in SAGE Research Methods Datasets Part 2 (London: SAGE Publications, Ltd., 2019) 2, https://www.doi.org/10.4135/9781526498878.
} 
Amazonian characters to determine gender hybridity. A narrative approach helps explain the implications of hybridity within the Amazons' respective narratives, demonstrating how existing in both gendered realms directly impacts the characters' experiences.

The texts I examined are Book 1 of Quintus Smyrnaeus' Posthomerica (The Fall of Troy) and the 2017 film Wonder Woman. ${ }^{32}$ Posthomerica is known among classics scholars as the definitive text for Penthesilea's story, as it is the longest surviving account. ${ }^{33}$ Wonder Woman is one of the most recent cinematic depictions of an Amazon. My decision to specifically analyze Penthesilea and Diana Prince together is based on the parallels of their narratives. Their stories both take place during a major war of their time (the Trojan War and World War I, respectively), and their main antagonists are hyper-masculine warriors (Achilles and Ares). Most importantly, as they are both Amazons, Penthesileia and Diana Prince possess masculine traits despite their female forms, fulfilling the precondition of gender hybridity.

For the thematic analysis, I applied open coding to both texts. I inductively created codes for all details that represented any gendered nuance, but I focused on three categories (expressions of power, personality traits, and appearance) that were deductively informed by previously established feminine/masculine dichotomies. ${ }^{34}$ Coded details included the characters' appearance, actions, dialogue, relationships, circumstances, lessons learned, and values. ${ }^{35}$ Both semantic and latent content were considered when creating codes. ${ }^{36}$ Then, these codes were organized into larger themes.

I used narrative analysis to interpret the themes covering Penthesilea's and Diana's masculinity, femininity, and hybridity. Within the contexts of their narratives and cultural-historical backgrounds, I focused on the main question of how gender hybridity affects Penthesilea's and Diana's abilities to exist as female figures in the typically masculine narrative of war. The analysis was informed by the literature and certain theoretical frameworks to increase interpretive validity and add substantial outside evidence. ${ }^{37}$ The flexibility of both thematic and narrative analyses allows for me as the researcher to maneuver around the various theoretical frameworks and rich qualitative content of my inquiry. This flexibility is also conducive to a novel approach that is necessary for my attempt to connect diverse concepts, disciplines, and modes of text.

\section{Foundations for chosen method}

Since Wonder Woman is situated as a cultural extension of the original Amazons, the foundational source must converse with recent material to reveal historical development. Martindale, an eminent scholar in classical reception,

\footnotetext{
${ }^{32}$ Full, detailed summaries of the plots are not given in this paper, as many parts of both stories are not relevant to the inquiry. Only information necessary for analysis will be mentioned in the discussion. Other background or plotlines might be provided in the footnotes for context.

${ }^{33}$ Proclus' summary of the lost epic Aethiopis (part of the epic cycle that includes the Iliad and Odyssey) and PseudoApollodorus' Bibliotheca (Epitome 5.1) also tell Penthesilea's story, but I did not analyze them because of the sufficiency of Posthomerica and the need to narrow my scope.

${ }^{34}$ See "Literature on Western Notions of Gender."

35 This all-encompassing approach to collecting data was based on Butler's performativity theory. See "foundations for chosen method" under "Approach." Data on Penthesilea will mostly be recorded as text, and data from Wonder Woman will be recorded as descriptions of scenes, cinematic choices, or dialogue script.

${ }^{36}$ Semantic content refers to explicit details, and latent content refers to underlying meanings and assumptions that have to be interpreted from the semantic content.

${ }^{37}$ See "foundations for chosen method" under "Approach." The theoretical frameworks include those of Martindale, Loraux, and Butler. An example of outside evidence includes the Homeric model drawn by Monsacré and Loraux, which guides interpretations of the characters' adherence to masculine forms of heroism.
} 
advocates this cross-cultural, transhistorical approach. ${ }^{38} \mathrm{He}$ defends comparisons of classical and postclassical literature by arguing that modern texts offer insight into ancient texts by removing them from an isolated, irrelevant, and static context. ${ }^{39}$ Furthermore, Martindale argues that history remains relevant to contemporary interpretations by common human experiences. ${ }^{40}$ In applying his logic with de Beauvoir and Butler's view on the historical constitution of gender, traditional gender norms can be used to analyze even contemporary texts such as Wonder Woman.

Loraux's studies on the division and exchange of gender associations in ancient Greek imagination serve as a precedent for my use of binary oppositions to explore gender hybridity. ${ }^{41}$ In The Experiences, where Loraux explores "the feminine [in] the Greek man," she employs binary oppositions as "conceptual tool[s]" to examine cases that "transcend" those oppositions. ${ }^{42}$ Darling-Wolf confirms that hybridity "retains the components of [the male/female] dichotomy." ${ }^{43}$ Darling-Wolf and Loraux support my approach of establishing masculine/feminine distinctions in Penthesilea and Diana before reflecting on how they coexist as gender hybridity. While Loraux provides a conceptual model for discovering hybridity, Butler provides the practical means of recognizing gendered traits within each character. Her gender theory of "performativity," or the repeating of public, mundane, and historically constituted acts that express one's gender, instructs my thematic analysis. ${ }^{44}$ In coding, individual "performances" of a character are organized into either expressions of femininity or masculinity based on the distinctions introduced in the literature review.

${ }^{38}$ See Martindale, "Redeeming the Text." His argument aligns with the new historicism theory, which several scholars have used to address the inadequacies of traditional approaches to the feminist and gender lens in classics.

${ }^{39}$ Conversely, aspects of society in classical antiquity can give insight into aspects of contemporary society if we accept the notion that "the understanding of the past is... the revelation of the present." Marilyn B. Arthur, "Early Greece: The Origins of Western Attitude Toward Women," Arethusa 6, no. 1 (1973): 16, accessed October 3, 2020, http://www.jstor.org/stable/26307462.

${ }^{40}$ Martindale cites C.S. Lewis, who coined this argument the "doctrine of the unchanging human heart." Martindale, 61. He also gives several analogies to explain this phenomenon: A musical piece such as Handel's Messiah can be performed at different times and occasions and still be relevant, similar to restoring old photos with "modern aesthetic preferences." Ibid., 64.

${ }^{41}$ For other studies that explore gender associations in fictional characters, see also: Emad; Helen Harper, "Studying Masculinity(ies) in Books about Girls," Canadian Journal of Education 30, no. 2 (2007): 508-30, accessed October 19, 2020, doi:10.2307/20466648; Loraux, Tragic Ways; Hélène Monsacré, The Tears of Achilles, trans. Nicholas J. Snead, Hellenic Studies Series 75 (Washington, DC: Center for Hellenic Studies, 2018), http://nrs.harvard.edu/urn3:hul.ebook:CHS_MonsacreH.The_Tears_of_Achilles.2018; Lisa Maurice, "Saviours, Six-Packs and Sensitivity: The Hero of Greek Mythology on the Contemporary Screen," Classicum 44, no. 2 (2018): 18-28, accessed September 16, 2020, http://search.ebscohost.com/login.aspx?direct=true\&db=asn\&AN=137653981\&site=ehost-live; Walcot, "Greek Attitudes towards Women."

${ }^{42}$ Loraux, The Experiences, 5, 116. She states it in another way: "When imbalance takes over, blurring even wellestablished antitheses... [the certainties must] be mobilized in order to find our way." Ibid., 6-9. Loraux's foundational argument is that Greek literature and drama feature characters that transcend essentialist boundaries, adopting traits commonly associated with the other gender. The concept of gender exchange and dual incorporation is so ingrained in Greek thought that androgyny, the English word describing the combination of the masculine and feminine, resembles the Greek word androgunoi (men-women). There is an entire spectrum of Greek words related to gender exchange.

${ }^{43}$ Ibid., 77. This is also consistent with Butler's view that gender distinctions "sustain discrete and binary categories," which informed the delineation of traditional notions of masculinity and femininity in the literature review. Butler, "Performative Acts," 523.

${ }^{44}$ See Butler, 519-31. To Butler, performativity is limited by historical and social contexts, but it is also an opportunity to challenge and resist these norms, especially in theatrical (fictional) settings that are rooted in but somewhat removed from reality. This theory bears close resemblance to Loraux's claim that gender expressed in Greek imagination both challenges and reinforces essentialist norms. A theatrical analogy is used to explain the abilities and limits of performativity: Just as an actor needs both the script and their own interpretation to perform on stage, gender according to the performativity theory is not a purely individual choice or an imposed mandate, but a dynamic interaction between the individual and the social, cultural, and historical constraints the individual exists in. Butler also makes an important distinction in that in a theatrical setting, a nonconforming performer may be excused and even praised, but in reality, the same nonconforming acts would be punished or criticized. 


\section{Delimitations and limitations}

The narrow scope of this investigation has several parameters. Although there are many renditions of Wonder Woman's and Penthesilea's stories, I focus in-depth on only one of each. Secondly, although gender performativity and hybridity are often discussed in queer studies, this inquiry does not attempt to provide insight into queer contexts. It uses masculine and feminine associations as conceptual elements for analyzing fictional female characters. The inquiry is not strictly under classics or film studies either. Although informed by these disciplines along with gender studies and history, my research follows an original, interdisciplinary approach. ${ }^{45}$

In this qualitative study, my role is as a collector, synthesizer, and interpreter of textual evidence. Although flexibility is advantageous for my interdisciplinary approach in a nascent area of inquiry, my subjectivity, biases, and lack of expertise render limitations on the reliability of my interpretations and conclusions. Therefore, I heavily depend on a variety of authoritative sources and theoretical frameworks to ensure robust logical reasoning in all parts of the research process. Also, since I cannot read ancient Greek, etymological differences in Loeb Classical Library's translation of Posthomerica must be noted.

\section{Findings}

After coding Book 1 of Posthomerica and the entirety of Wonder Woman, numerous preliminary codes and several overarching codes emerged. From these codes, five themes were extracted. To be succinct, the entire codebook is not presented; instead, a description of the five themes with examples from both texts summarizes the data (see table 1). In the following analysis, these five themes are discussed in four broader categories of masculinity, femininity, defeat (encompassing the last two themes of death and disguise), and beauty.

Table 1. Final Themes.

\begin{tabular}{|l|l|l|}
\hline Theme & Description & Example \\
\hline Warrior spirit and status & $\begin{array}{l}\text { Related to the warrior identity, "And glorious Penthesilea, who pur- } \\
\text { largely informed by the Homeric } \\
\text { epic hero model. }{ }^{46} \text { Can extend to } \\
\text { qualities associated with the public } \\
\text { sphere and other related masculine } \\
\text { traits such as aggression and brute } \\
\text { strength. }\end{array}$ & $\begin{array}{l}\text { fled ranks, while ever waxed her val- } \\
\text { our more and more... Her aweless } \\
\text { spirit failed for weariness nor } \\
\text { fainted, but her might was adaman- } \\
\text { tine."47 }\end{array}$ \\
& $\begin{array}{l}\text { Diana: "Where I come from, gener- } \\
\text { als don't hide in their offices like } \\
\text { cowards. They fight alongside their }\end{array}$ \\
\hline
\end{tabular}

${ }^{45}$ For example, various film or popular culture theories may help me interpret the techniques unique to Wonder Woman, but these theories will not be main guiding frameworks but rather tools to understand the source text better. This applies to theories in classics and Posthomerica as well.

${ }^{46}$ The "model of the ideal Homeric epic hero" will be largely informed by Loraux and Monsacré.

${ }^{47}$ Quintus Smyrnaeus, The Fall of Troy 1.515-525, trans. A. S. Way, Loeb Classical Library Volume 19, (London: William Heinemann, 1913). 


\begin{tabular}{|c|c|c|}
\hline & & $\begin{array}{l}\text { soldiers. They die with them on the } \\
\text { battlefield." } 48\end{array}$ \\
\hline Tenderness & $\begin{array}{l}\text { Feminine qualities such as empathy, } \\
\text { maternal instincts, intimacy, and/or } \\
\text { associations with peace, light, and } \\
\text { joy. }\end{array}$ & $\begin{array}{l}\text { "Gladdened a little while was } \\
\text { Priam's soul... sore longing to be- } \\
\text { hold the light [Penthesilea]." } 49 \\
\text { Diana: "We cannot leave without } \\
\text { helping... [the] women and chil- } \\
\text { dren." } 50\end{array}$ \\
\hline Beauty and desirability & $\begin{array}{l}\text { Qualities related to physical attrac- } \\
\text { tion or sexuality that may allure men } \\
\text { or make the character an object of } \\
\text { desire. }\end{array}$ & $\begin{array}{l}\text { "Rose, like the breaking of the } \\
\text { dawn, to view "neath dainty-pen- } \\
\text { cilled brows a lovely face... the war- } \\
\text { riors gazed, and in their hearts they } \\
\text { prayed that fair and sweet like her } \\
\text { their wives might seem." } 51 \\
\text { Sameer: "That's a work of art... [in } \\
\text { Spanish] your eyes, as soft as your } \\
\text { smile... [in French] All I want right } \\
\text { now is a picture of your lovely } \\
\text { face." } 52\end{array}$ \\
\hline Death & $\begin{array}{l}\text { All allusions to eventual doom and } \\
\text { defeat. Exclusive to Penthesilea. }\end{array}$ & $\begin{array}{l}\text { "He had no vision of ruin onward } \\
\text { rushing upon himself and Troy, and } \\
\text { Penthesilea's self withal." }\end{array}$ \\
\hline Disguise & $\begin{array}{l}\text { Exaggerating or hiding either femi- } \\
\text { nine or masculine qualities for a so- } \\
\text { cial agenda). }{ }^{54} \text { Exclusive to Diana. }\end{array}$ & $\begin{array}{l}\text { Steve: “[Diana]’s my, um... secre- } \\
\text { tary, sir." } 55\end{array}$ \\
\hline
\end{tabular}

\section{Analysis/Discussion}

The first half of my discussion explores the masculine and feminine qualities in Penthesilea and Diana, empirically establishing their gender hybridity. The second half takes a closer look at the implications of the characters' hybridity for their positions in male realms of power, especially examining the themes of desirability and defeat. From there, a trend of change and continuity in Western perceptions of hybrid female power is extracted.

${ }^{48}$ Wonder Woman, directed by Patty Jenkins, (United States: Warner Bros. Pictures, 2017).

${ }^{49}$ Smyrnaeus, The Fall of Troy 1.88-99.

${ }^{50}$ Wonder Woman, directed by Patty Jenkins.

${ }^{51}$ Smyrnaeus 1.899-900, 1.914-915.

${ }^{52}$ Wonder Woman. One of Diana's male teammates gushes about her beauty a few seconds after they meet.

${ }^{53}$ Smyrnaeus, 1.500-503. The narrator alludes to Penthesilea's imminent doom as an unnamed Trojan soldier blindly puts his trust in her victories.

${ }^{54}$ See Wonder Woman's adoption of "female-female impersonator" or "trickster figure" roles in Emad, 964. Further discussion in "Analysis."

${ }^{55}$ Wonder Woman. To explain the unwarranted presence of Diana (a woman) in the war council room (only filled with men during World War I), Steve hides Diana's true identity and calls her his secretary instead. 


\section{Masculinity and heroism}

The Homeric model for heroism is fundamentally masculine, characterized by the epic hero who faces suffering squarely. ${ }^{56}$ Masculine warfare involves close contact and direct strikes to the core areas of the body, including the back, belly, and chest. ${ }^{57}$ Both Penthesilea and Diana demonstrate capacities for violence, great physical and mental strength, and confrontational combat, making them masculine heroes in the Homeric vein.

Smyrnaeus depicts Penthesilea's ferocity through allusions to celestial and animalistic imagery. He likens her to Zeus' lightning and a lioness. With her double-bladed halberd, she leads the Trojan men into battle, acting as an impetus for their courage. All the while, her "fury [neither] fainted nor failed." ${ }^{58}$ Diana possesses similar innate belligerence. Within the first five minutes of the film, her aunt Antiope compares her to a scorpion who "must sting" and a wolf who "must hunt." ${ }^{59}$ Diana's demonstration of brute force peaks in the climactic battle against Ares, in which she charges at him with her sword brandished, hurls a tank with her bare hands, and outwardly expresses her explosive wrath. ${ }^{60}$ This is also when Diana discovers that the "Godkiller," the only weapon that could defeat Ares, is not a physical sword but herself. ${ }^{61}$ The literal connection between Diana and her source of power explicitly reflects the Homeric idea that the weapon is an extension of the warrior's self. ${ }^{62}$ These Homeric qualities bring Penthesilea and Diana success, fame, and leadership on the battlefield. In combat and through masculine means, their glory is achieved.

Perhaps equally important in achieving warrior status is a trend involving a dichotomy discussed in the literature review: the exit out of the feminine, private sphere and entrance into the masculine, public sphere. Classicist Monsacré states that "in the universe of the Iliad... in order to define heroism, one must pass through the world of women and... radically distinguish oneself from it." ${ }^{63}$ In both Amazons, the eagerness to fight pushes them into war. Penthesilea's "lust of fight," emphasized by the physical manifestation of her unmatched speed, drives her from Troy's palace walls. ${ }^{64}$ She also ignores Andromache's warnings against going into battle. ${ }^{65}$ With this defiance of female counsel, Penthesilea passes through and distinguishes herself from "the world of women."

Diana expresses an eagerness to fight from a young age and presses her protective mother, Hippolyta, to let her start training. Her ultimate move into the public world of men, however, begins when she defies Hippolyta's command

\footnotetext{
${ }^{56}$ Hélène Monsacré, The Tears of Achilles.

${ }^{57}$ Ibid.

${ }^{58}$ Smyrnaeus, 1.419-420.

${ }^{59}$ Wonder Woman.
}

${ }^{60}$ Ibid. A theme song from the soundtrack titled "Wonder Woman's Wrath" explicitly demonstrates the emphasis on Diana's emotional expression of her physical power through wrath, a word commonly associated with Penthesilea in Posthomerica as well.

${ }^{61}$ Ibid.

${ }^{62}$ Monsacré. Diana also adheres to ancient ideals of heroism when she attributes indirect combat to cowardice. She retorts to war generals, "How do you know who you kill if you can't see their face?... You fight without honor." The example given in the Findings section under the theme of "warrior spirit and status" further demonstrates how she advocates fighting outside in the battlefield rather than strategizing indoors. Wonder Woman.

${ }^{63}$ Monsacré.

${ }^{64}$ Smyrnaeus, 1.552 .

${ }^{65}$ See an excerpt of Andromache's warning in the subsection "Defeat: death and disguise." Penthesilea's shift into the masculine realm is even more explicit when comparing her interaction with Andromache with Hector's parallel interaction with Andromache in the Iliad. Like Penthesilea, he dismisses Andromache's warnings and pleas to stay with her in the palace. Since up to the point of his death, Hector was considered Troy's greatest hero, the symbolic replacement of Hector with Penthesilea (King Priam, Hector's father, even greets Penthesilea as if she were his daughter) suggests a close association between Hector's and Penthesilea's masculine heroism. 
against joining Steve Trevor, a soldier who crashed on her island, to fight in the Great War ${ }^{66}$ Claiming that accompanying Steve is essential to her duty and identity, Diana officially separates herself from the idyllic, private island of peace and femininity. She enters the masculine sphere of war and nationhood, where she pursues the full potential of her heroism.

\section{Feminine Tenderness}

Femininity in these characters is recognized as empathic, nurturing, intimate and peaceful. The word "tenderness" was chosen as an umbrella term for these qualities to contrast against the more aggressive nature of masculine militarism.

Marston's foundational belief in feminine superiority is shown in the film when Hippolyta reveals the pacifist origins of the Amazons: "The gods created us... to influence men's hearts with love and restore peace to the Earth." 67 Hippolyta explicitly condemns masculine notions of heroism by stating that "fighting does not make you a hero." 68 Although Diana initially defies her mother and responds to masculine callings, her core values remain pacifist and empathetic. Her ancestral mission to preserve peace in the world is reflected in her determination to defeat Ares, whose death she believes will end all wars. ${ }^{69}$ She joins the war not for glory or conquest but to protect innocent lives. She acts as an Artemis figure for the weak, pulled by her empathy and sense of responsibility towards children, women, and animals in need. ${ }^{70}$

Diana's expression of power on the battlefield also exhibits femininity. Even as she proves her brute strength in direct combat, she heavily depends on defensive-one could say feminine-warfare. Her main source of power, her wrist cuffs, blocks and counters offensive fire (see fig. 1). However, the main lesson Diana learns throughout the film, "that only love can truly save the world," illustrates the ultimate feminine aspect of her heroism. ${ }^{71}$ At the peak of her strength in the final battle, she tells Ares, "I believe in love." 72 Her warm smile moments before defeating him signals her satisfaction and confidence in her ability to love (see fig. 2). Diana's ultimate victory through personal and universal love reinforces the superiority of feminine tenderness that Marston advocated. It also demonstrates the thirdwave feminist goal of "reclam[ing] signs of femininity as empowering. ${ }^{73}$

\footnotetext{
${ }^{66}$ Steve's crashing into Themyscira's waters symbolically exposes Diana to the outside (public) masculine realm of war even before she leaves the island.

${ }^{67}$ Wonder Woman.

${ }^{68}$ Ibid.

${ }^{69}$ The irony here is that in the original Greek myths of the Amazons, Ares is their father and patron god. The Amazons live by their brutal, bloodthirsty father's love of war. In the DC universe, Wonder Woman and her Amazon sisters are sworn enemies of Ares, and Aphrodite is their patron goddess and the feminine antithesis to Ares. In the first issue of Sensation Comics (the first ongoing series with Wonder Woman as the main character) Ares claims, "my men shall rule with the sword," to which Aphrodite responds, "my women shall conquer men with love." Penrose, 196.

${ }^{70}$ As referenced previously, Diana's name is the same as that of Artemis' Roman iteration. In Greek mythology, Artemis acts as a patron of young girls and childbearing women.

${ }^{71}$ Ibid. The song that plays in the end credits, "To Be Human," also reinforces this message, saying that love is the key to being human.

${ }^{72}$ Ibid. It is also significant that the way Diana defeats Ares is that she turns his power (his lightning bolts) back on him through her wrist cuffs. This shows Diana's feminine, defensive combat style and also establishes the irony of masculine aggression's self-destructive nature.

${ }^{73}$ Cocca, 98. Third-wave feminism is the most recent feminist movement to date. It extends beyond the first-wave goal of achieving legal equality and the second-wave goal of liberation to aim for inclusivity, expression, and individual choice. Marston was a first-wave feminist, while de Beauvoir is classified under the second wave.
} 


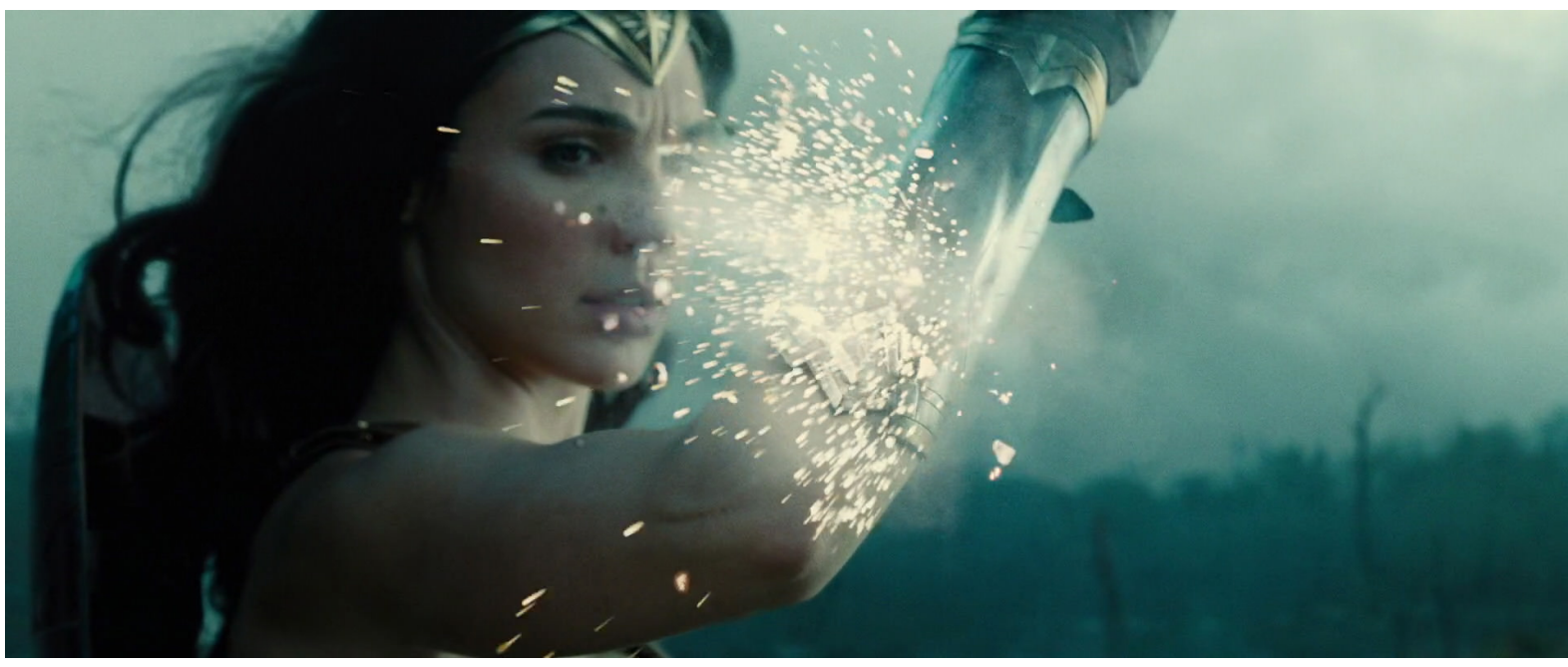

Fig. 1. Diana deflects a bullet with her wrist cuff. (Warner Bros. Pictures, 2017. Screenshot from Movie-Screencaps.com).

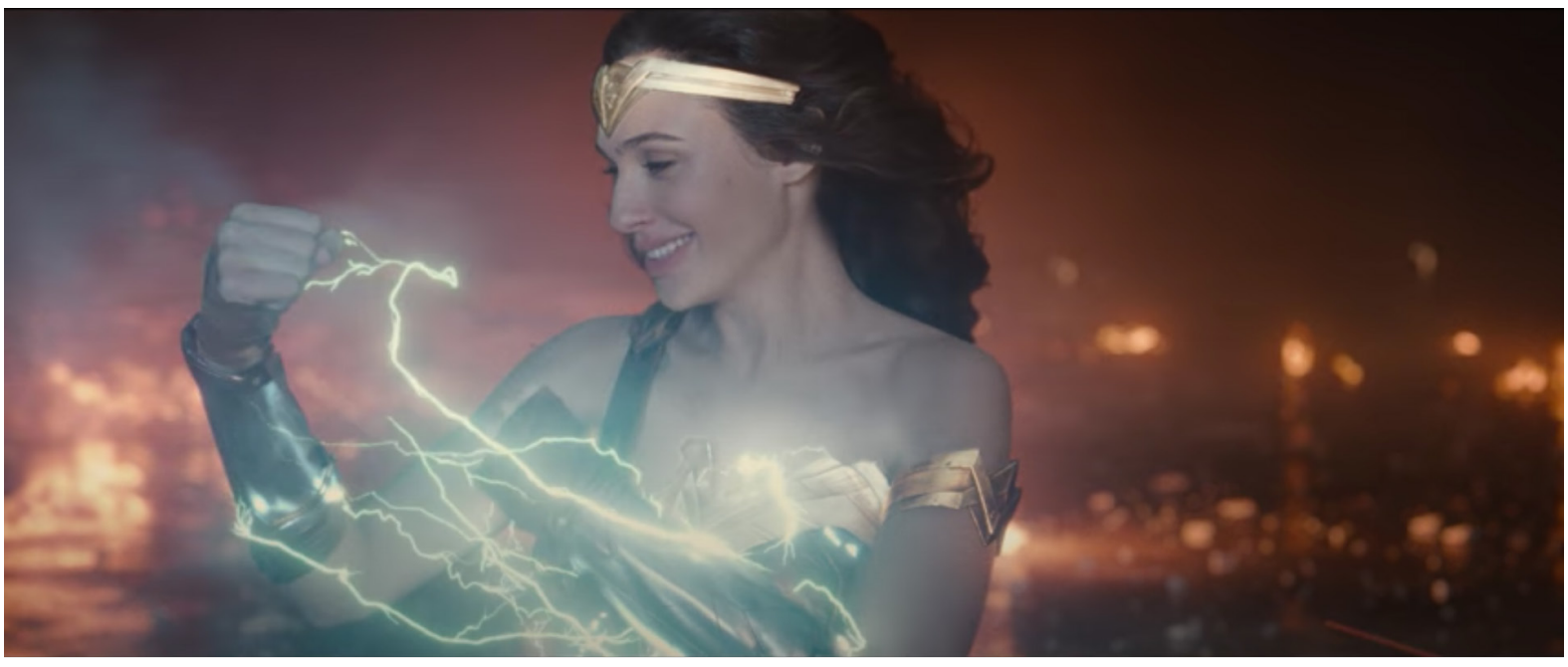

Fig. 2. Diana smiles during the final battle. (Warner Bros. Pictures, 2017. Author's screenshot).

Demonstrating both masculine and feminine approaches to warfare and by gaining victory through both brute strength and the power of love, Diana's hybridity is closely related to her status as a warrior. Penthesilea's hybridity, on the other hand, is more nuanced. Tenderness is rarely attributed to her. Her femininity is explicit only in passing comparisons of her as a bringer of peace, light, and joy, yet these too are closely tied to her masculine prowess as a warrior. Instead of attributing her femininity to internal qualities that define her character, Smyrnaeus emphasizes Penthesilea's femininity in her interactions with Achilles, her male counterpart. Her hybridity only manifests in her defeat by his hypermasculine form. Thus, this dynamic will be discussed further in the second half of this analysis along with the consequences of Diana's and Penthesilea's hybridity.

Defeat: death and disguise 
The most common ending to an Amazon's story is death. These foreign warriors oppose the mightiest Greek heroes in battle, but despite their purported equal strength, they are reduced to merely "an index of heroic achievement" for male figures. ${ }^{74}$ Their dead bodies are trophies for Greek heroes to prove their superiority. As figures so rooted in masculinity, their mortality is linked to their femininity and hybridity. The ancient logographer Lysias announced in his Funeral Oration that "by their disasters rather than by their bodies [the Amazons] were deemed to be women" and that in defeat, "their weak, feminine nature is paramount." 75 Amazonian defeat, therefore, resembles feminine submission rather than heroic tragedy.

Penthesilea is no exception. When she meets Achilles, the formerly undefeated Amazon falls swiftly under his blade. In Smyrnaeus, an Amazon's failure is further associated with her ambition to enter masculine spheres. Her hybridity is disregarded as impossible and therefore foolish. With this message, Quintus Smyrnaeus admonishes Penthesilea to control her confidence through Andromache's lament in his Posthomerica (The Fall of Troy):

Ah hapless! why with arrogant heart dost thou

Speak such great swelling words? No strength is thine

To grapple in fight with Peleus' aweless son [Achilles].

Nay, doom and swift death shall he deal to thee.

Alas for thee! What madness thrills thy soul?

Fate and the end of death stand hard by thee! ${ }^{76}$

Penthesilea does not heed these words and proudly slaughters her way to confront Achilles in true heroic fashion. Throughout her victories, Penthesilea is constantly warned against pursuing warfare. The "invisible hand" of eventual doom leads her on. ${ }^{77}$ Finally, as if by divine punishment for her audacity, Penthesilea is killed by Achilles. Her death becomes a cautionary tale told by Achilles as he mocks her dying self:

Nay, but it was the darkness-shrouded Fates

And thine own folly of soul that pricked thee on

To leave the works of women, and to fare

To war, from which strong men shrink shuddering back. ${ }^{78}$

Achilles chastises Penthesilea for crossing over into the masculine realm, humiliating her for her naivety in thinking she could win in the world of men. Achilles' message is clear for all Amazons and all women: Transgress the boundaries of proper behavior for your gender, and there will be punishment. The silent warnings of fate and Achilles' remark invalidate her hybridity and disallow her adoption of masculinity as an advantageous strength. Penthesilea's "feminine" defeat and death override her previous masculinity. Her femininity is only expressed as a punitive nullifier of hybridity and reinforcer of essentialism.

Diana's arc does not end with death as Penthesilea's does, but she is symbolically defeated by her constant need to compromise her masculinity or femininity to be respected as a superhero and accepted as a woman. Hybridity does not escape hegemonic norms for her either. One way Diana compromises is through disguising her hybrid strengths as she navigates through the world of men. ${ }^{79}$ Most times, these disguises are imposed on her by Steve as he

\footnotetext{
${ }^{74}$ Hardwick, 16. The Greek word for this heroic excellence is aristeia.

${ }^{75}$ Hardwick, 28; Penrose, 183.

${ }^{76}$ Smyrnaeus, 1.119-124.

${ }^{77}$ Ibid., 1.532 .

${ }^{78}$ Ibid., 1.887-890.

${ }^{79}$ Emad, 964. Emad emphasizes the fact that throughout the history of the character, Wonder Woman is forced to take on the role of a "female-female impersonator" or a "trickster figure." These terms are used by Emad to signify the
} 
underplays and overplays her femininity to accommodate for social norms. For example, he makes her wear glasses to "look less distracting" (see figs. 3 and 4). Diana must obscure her beauty to be taken seriously in the male-dominated realms of the public and war. On the other hand, Steve introduces Diana as his secretary and blind sister to the generals in the war council to excuse her assertiveness and unapologetic presence in a room of men. ${ }^{80}$ Using McCall's "believable femininity" argument, Diana is more easily accepted as female in these submissive roles. The immense difficulty of Diana's acceptance as a hero and a female possessing both feminine and masculine traits reflects the tensions between the harshly divided spheres of femininity and public power. ${ }^{81}$ Although in the film, the physical disguises are eventually rejected (Diana's glasses are broken), Diana's compromised hybridity reinforces Darling-Wolf's claim that hybridity's resistance "against hegemonic practices is often fragile" (see fig. 5) ${ }^{82}$ Even as hybridity empowers Diana's heroism, it meets obstacles in social contexts where patriarchal and essential influences undermine the acceptance of hybrid existences.

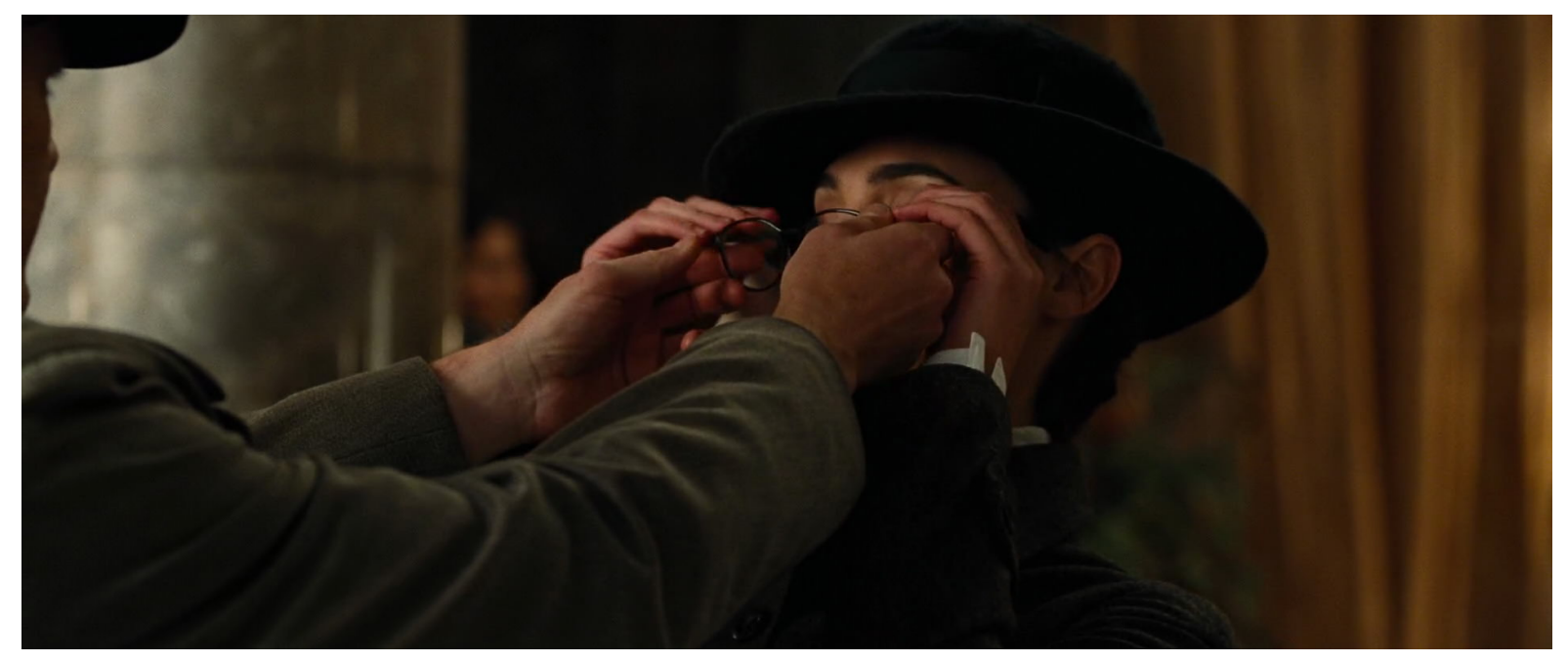

Fig. 3. Steve puts glasses on Diana. (Warner Bros. Pictures, 2017. Screenshot from Movie-Screencaps.com).

fake roles Wonder Woman has to adopt to hide her full powers from others' awareness. One example of this in the original comics is when Diana works as a nurse and secretary (more commonly female jobs) to cover or even replace her superhero identity.

${ }^{80}$ Wonder Woman.

${ }^{81}$ See Emad.

${ }^{82}$ Darling-Wolf, 66. 


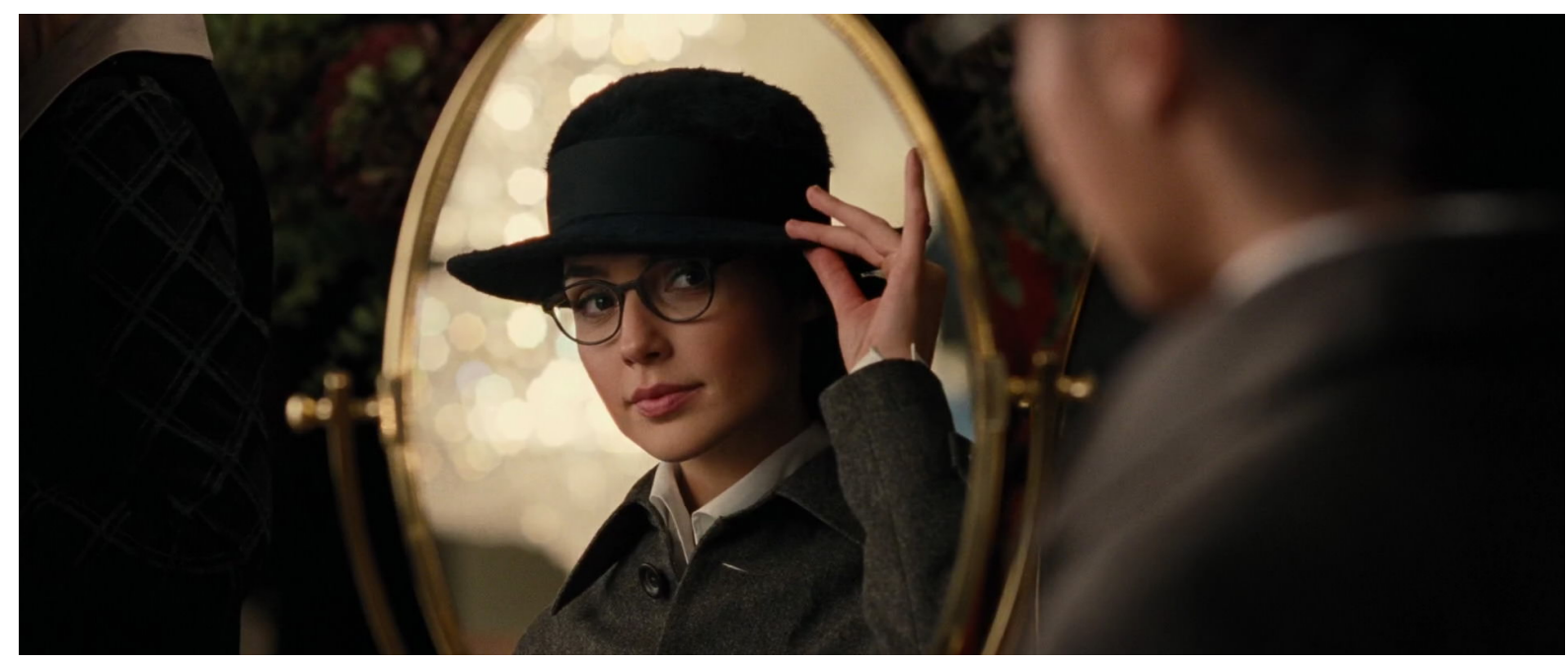

Fig. 4. Diana looks in the mirror with glasses. (Warner Bros. Pictures, 2017. Screenshot from Movie-Screencaps.com).

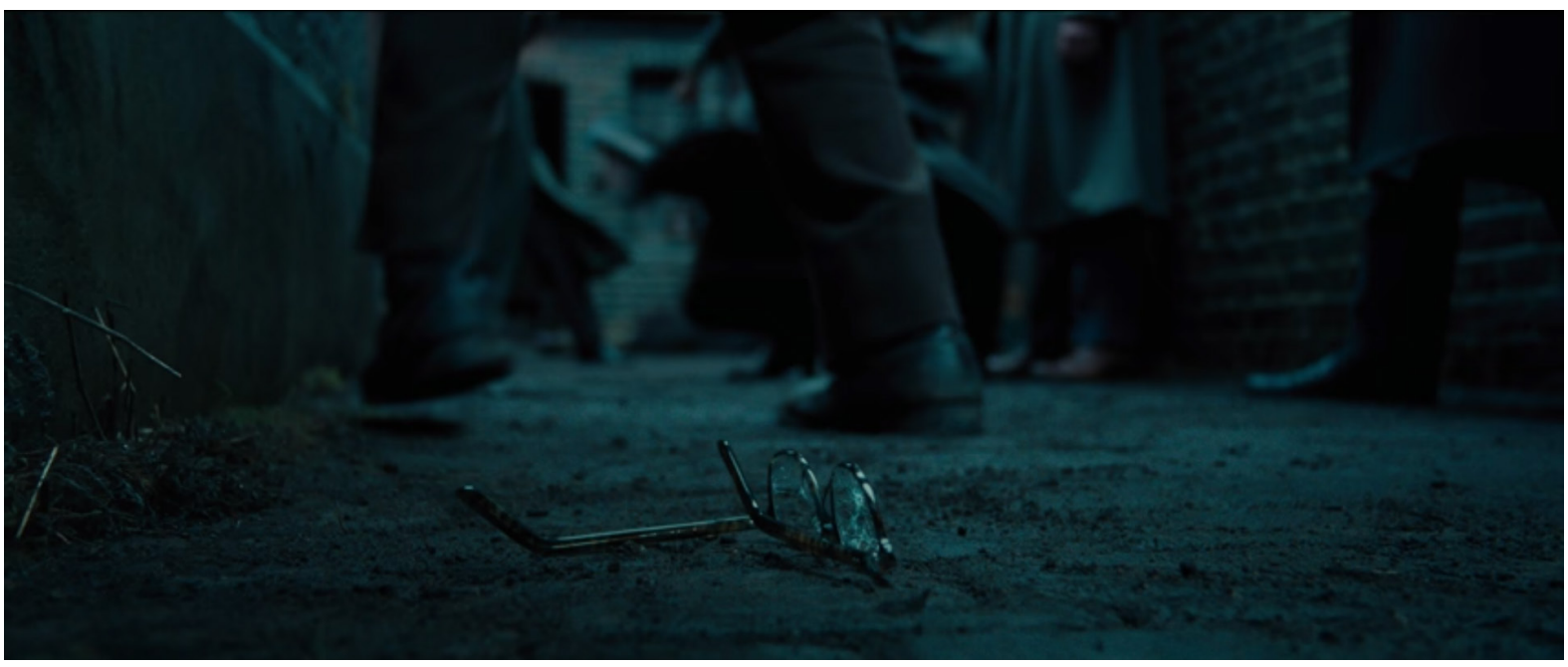

Fig. 5. Diana's glasses are broken during a fight. (Warner Bros. Pictures, 2017. Author's screenshot).

\section{Beauty, desirability, and sexuality}

As McCall predicted, the role of female sexuality and male desire is also significant in creating believable femininity and compromising hybridity. When Penthesilea is killed, she is not only defeated physically and symbolically but also sexually. ${ }^{83}$ Achilles and the other Greek men crowd over her fallen body, admiring its beauty and "pray[ing] that fair and sweet like her their wives might seem." ${ }^{84}$ In becoming an inanimate object of admiration, the dead Penthesilea fulfills the feminine role of silently satisfying male desire. Furthermore, her association with wifedom, an unthinkable status to the Amazons, follows the mythological pattern in which the "taming of the Amazons by [love]" returns "these

\footnotetext{
${ }^{83}$ Some versions of the story take this idea literally, alluding to the possibility that Achilles committed necrophilia on Penthesilea's corpse.

${ }^{84}$ Smyrnaeus, 1.914-915.
} 
women to their "natural state' in a patriarchy." ${ }^{85}$ A Greek marriage, even hypothetically, traps Penthesilea in the entirely feminine realm of the home and motherhood, ending further possibilities of hybridity.

Yet, ambiguities rise in analyzing Penthesilea's relationship to physical beauty. While feminine beauty is established as "intrinsically erotic," Penthesilea's "fearsome beauty" is many times associated with her masculine prowess as a warrior. ${ }^{86}$ In fact, in most Greek narratives, an eroticized death as Penthesilea's would "[belong] fully to the masculine, heroic sphere" and possibly lead to her climactic achievement of kleos aphthiton (undying glory). ${ }^{87}$ Moreover, Aphrodite, the goddess of feminine sexuality, enhances Penthesilea's beauty after death to pierce Achilles "with the sharp arrow of repentant love." ${ }^{88}$ Considering the Greeks' belief that beguiling beauty was a feminine attack resembling military conquest against the rational male mind, Penthesilea's unique power over Achilles' emotions is a possible suggestion of her ultimate, though entirely feminine, victory. ${ }^{89}$

Diana's relationship with her feminine sexuality is just as complex. While her beauty is presented as mutually exclusive with respectable heroism when Steve forces her to wear glasses, it could also be seen as empowering. Her beauty is highlighted in moments revealing her positive feminine qualities of empathy and intimacy. On the other hand, Diana plays the "patriarchal bargain" to gain an advantage over men by accentuating her sexuality. ${ }^{90} \mathrm{~A}$ clear example is when she enters a gala held for the Germans in a blue gown with the hidden intention of killing her enemy General Ludendorff (see fig. 6). She attracts attention to herself, which paradoxically disguises her aggressive power from being threatening. She implicitly seduces Ludendorff with a dance as she tries to kill him. ${ }^{91}$ As with her other disguises, Diana exploits her sexuality in ways acceptable to patriarchal, essential notions of femininity to secure her position as an able hero.

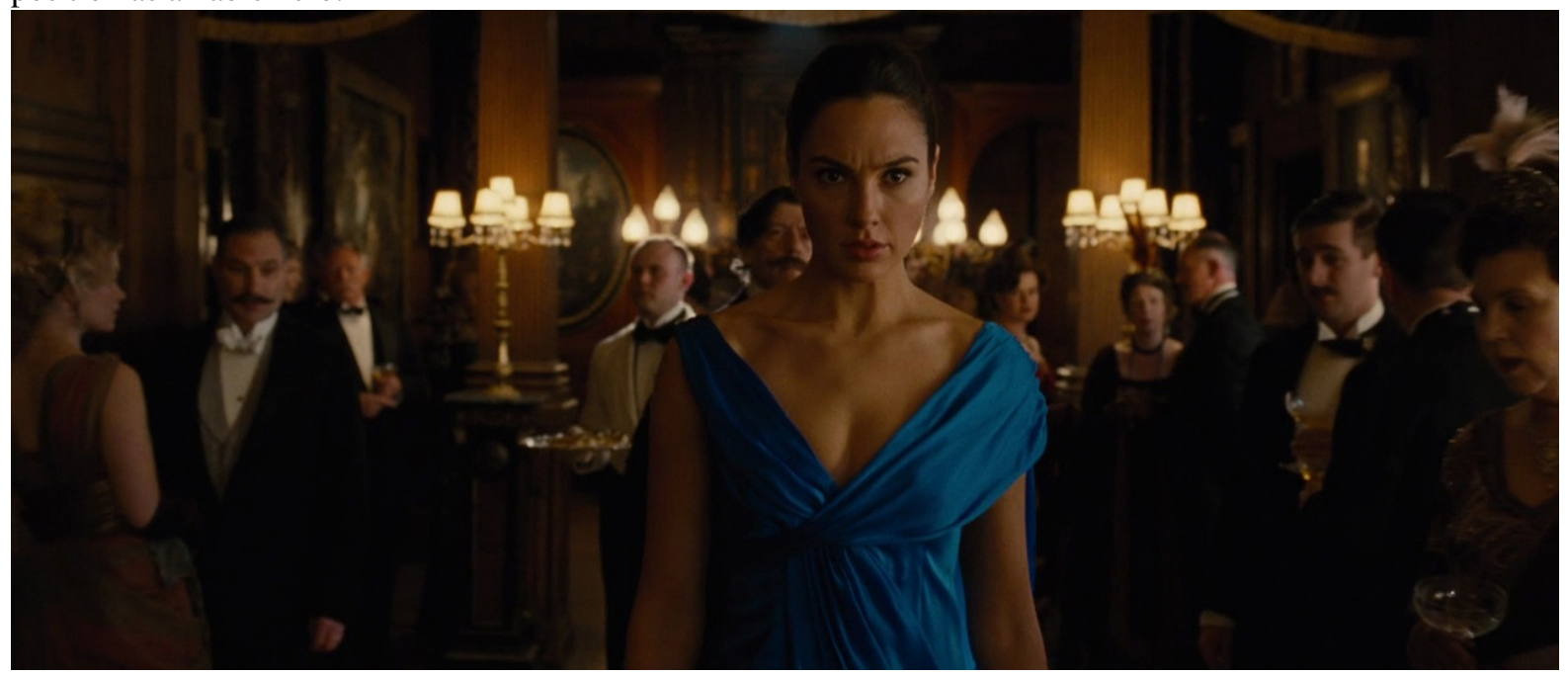

Fig. 6. Guests at the gala stare at Diana. (Warner Bros. Pictures, 2017. Screenshot from FilmGrab.com).

\footnotetext{
${ }^{85}$ Fantham et al., 131. This discourse on the Amazons' defeat by the Greek, patriarchal institute of marriage most famously includes the story of Antiope, an Amazon who was kidnapped by the Athenian hero Theseus and made his wife.

${ }^{86}$ Blondell, 2; Smyrnaeus.

${ }^{87}$ Monsacré.

88 Smyrnaeus.

${ }^{89}$ See literature review or Blondell discussing Greek anxieties about the powers of female sexuality.

${ }^{90}$ The patriarchal bargain refers to the strategies women use that conform to or are bound by the norms of a patriarchal society yet paradoxically grant women greater autonomy and security within such oppressive confines. See Corey Albertson, "The New Wonder Woman," Contexts 15, no. 3 (2016): 68, accessed October 24, 2020, https://doi.org/10.1177\%2F1536504216662253.

${ }^{91}$ Wonder Woman.
} 


\section{Summary}

For the Greeks, hybridity acted as a warning. Their central philosophy of essentialism was maintained by punishing the Amazons that challenged it. Thus, Penthesilea's heroic qualities are strictly masculine. In her defeat, femininity nullifies any previous signs of hybridity, reinforces gender essentialism, and restricts her presence in the male realm of power. Yet the various ambiguities in Penthesilea's story tease the possibility that despite normalizing hegemonic distinctions, the Greeks were intrigued by the idea of equality between the genders. Nonetheless, stories of the Amazons challenging gender boundaries add enticing tension in the Greeks' otherwise stringent collective consciousness.

Wonder Woman's hybridity, in contrast, was created for the clear purpose of empowerment. To Marston, femininity was supreme, and combining the positive qualities of femininity with masculine assertiveness was the formula for the ideal woman. Diana's hybridity enables her to become a greater warrior, as she can utilize both masculine and feminine strengths on and off the battlefield. Her hybrid form of heroism empowers her position in the public, male realms of war and statehood. However, Diana struggles to uphold the mighty potential of her hybridity when faced with the need for social acceptance. Juggling the potential of her power and the immense pressure of centuries-old traditions threatening to trap her into the limiting realm of believable femininity, she must compromise, disguise, and bargain her hybridity. Nevertheless, the film closes with the victorious Diana warmly embracing the power of love towards humanity, ultimately making Diana a hybrid hero propagating the virtues of femininity.

\section{Conclusion}

For centuries, the Amazons have symbolized gender hybridity imbued in powerful female figures, which inextricably ties them to the cultural and sociopolitical history of the West. The ancient and modern texts examined in this inquiry weave masculinity and femininity in the narratives of Penthesilea and Diana. Through hybridity, essentialist and hegemonic gender norms are enforced or challenged. These consequences of hybridity demonstrate each period's contrasting and lasting notions of gender, womanhood, and their place in the public sphere. Besides the various limitations in interpretive validity and impartiality previously delineated in the explanation of my approach, there are limits to the universality of my findings. Firstly, an absolute conclusion is difficult to extract from the ambiguities arising from the analysis that qualify the distinctions dividing the ancient and modern perspectives. However, from both Amazons' experiences of defeat or compromise, it is obvious that the realms of femininity and public power cannot coexist comfortably in either Greek mythology or modern cinema. Furthermore, the existence of ambiguities shows how the struggle in reconciling imagination with reality is reflected in cultural texts.

Secondly, the narrow scope of the inquiry limits the applicability of insights found to a small range. The specificity of this inquiry allows the focused use of eclectic lenses combining diverse perspectives across disciplines to connect and develop new ideas that transcend historical, cultural, and contextual boundaries. However, out of the contexts of Posthomerica and Wonder Woman, and especially out of the context of the Amazon trope, ideas about gender hybridity and power may have less relevance. Nevertheless, the multi-faceted approach used in this inquiry is supported with enough theoretical frameworks to replicate when analyzing other cultural texts in the Western discourse on women and power. Nomadic warrior women from all over world history and mythology inspired the Western creators of the Amazon Xena in Xena: Warrior Princess, Disney's rendition of Mulan from Chinese legend, Marvel Comics' adoption of the valkyries from Nordic mythology, and the sub-Saharan Dora Milaje of the Black Panther stories. Future studies on such characters may further the discourse on gender hybridity's role in Western ideas of powerful women while addressing the recent demands of intersectionality in the third wave of feminism.

The real Amazons of today are the countless women who occupy spaces and assume roles that have been

labeled "male" for centuries. In social, professional, and personal settings, gender hybridity, which Darling-Wolf claims is deeply embedded in the "micropolitical practices of daily life and daily resistances," has a legitimate oppor- 
tunity to challenge hegemonic establishments. ${ }^{92}$ Embracing gender hybridity as a normative practice may open avenues for both men and women to previously restrictive spheres of influence. Through new fictional representations of gender hybridity and adaptations of historically hegemonic tropes, we can start imagining such an inclusive future. De Beauvoir's notion that gender is historically constituted implies that cultural representations of gender inform social norms and vice versa. Thus, imagination in mediums such as film can manifest in reality, and reclaiming cultural traditions such as the Amazon trope from Greek mythology can be invaluable for the modern audience.

\section{Acknowledgments}

I am forever grateful for all of the support I have received. Thank you to Natalie Swain for your long emails and for reading through all of my work, from the inquiry proposal to the final draft. Your comments expanded and deepened my understanding, and they never failed to make me even more intrigued by my topic. You made me feel less alone in this foreign area of research. Thank you to the senior AP Research "alumni" whose advice assured me that this was all achievable. To my AP Research classmates, everyone's incredible diligence, creativity, and camaraderie is what inspired me to keep going. Last but not least, I cannot fully express how much I am grateful for Ms. Bethany Stallings, my AP Research teacher. Your constant support and investment in my inquiry is what made it possible.

\section{References}

Albertson, Corey. "The New Wonder Woman.” Contexts 15, no. 3 (2016): 66-69. Accessed October $24,2020$. https://doi.org/10.1177\%2F1536504216662253.

Andrews, Samantha. “Thematic and Narrative Analysis in the Context of Courtroom Examinations With Alleged Victims of Child Abuse.” In SAGE Research Methods Datasets Part 2. London: SAGE Publications, Ltd., 2019. https://www.doi.org/10.4135/9781526498878.

Arthur, Marilyn B. "Early Greece: The Origins of Western Attitude Toward Women.” Arethusa 6, no. 1 (1973), 7 58. Accessed October 3, 2020. http://www.jstor.org/stable/26307462.

Blondell, Ruby. "The Problem of Female Beauty." In Helen of Troy: Beauty, Myth, Devastation. N.p.: Oxford Scholarship Online, 2013. doi:10.1093/acprof:oso/9780199731602.001.0001.

Butler, Judith. "Performative Acts and Gender Constitution: An Essay in Phenomenology and Feminist Theory." Theatre Journal 40, no. 4 (1988): 519-31. Accessed October 10, 2020. doi:10.2307/3207893.

Cocca, Carolyn. "Negotiating the Third Wave of Feminism in "Wonder Woman"." PS: Political Science and Politics 47, no. 1 (2014): 98-103. Accessed September 6, 2020. http://www.jstor.org/stable/43284491.

Darling-Wolf, Fabienne. "Disturbingly Hybrid or Distressingly Patriarchal? Gender Hybridity in a Global Environment.” In Hybrid Identities: Theoretical and Empirical Examinations. Edited by Keri E. Iyall Smith and Patricia Leavy. Leiden: Brill, 2008.

Emad, Mitra C. "Reading Wonder Woman's Body: Mythologies of Gender and Nation." The Journal of Popular Culture 39, no. 6 (2006): 954-984. Accessed October 1, 2020. doi:10.1111/j.1540-5931.2006.00329.x.

92 Darling-Wolf, 67. 
Fantham, Elaine, Helene P Foley, Natalie Kampen, Sarah B Pomeroy, and H Alan Shapiro. Women in the Classical World: Image and Text. New York: Oxford University Press, 1994.

Hardwick, Lorna. “Ancient Amazons - Heroes, Outsiders or Women?” Greece \& Rome 37, no. 1 (1990): 14-36. Accessed September 6, 2020. http://www.jstor.org/stable/643239.

Harper, Helen. "Studying Masculinity(ies) in Books about Girls." Canadian Journal of Education 30, no. 2 (2007): 508-30. Accessed October 19, 2020. doi:10.2307/20466648.

Herodotus. The Histories. Edited and translated by A.D. Godley. Loeb Classical Library. Cambridge: Harvard University Press, 1920.

Jenkins, Patty. Wonder Woman. Los Angeles, CA: Warner Bros. Pictures, 2017.

Loraux, Nicole. The Experiences of Tiresias: The Feminine and the Greek Man. Translated by Paula Wissing. Princeton: Princeton University Press, 1995.

—. Tragic Ways of Killing a Woman. Translated by Anthony Forster. Cambridge: Harvard University Press, 1987.

Martindale, Charles. "Redeeming the Text: The Validity of Comparisons of Classical and Postclassical Literature (A View from Britain)." Arion: A Journal of Humanities and the Classics 1, no. 3 (1991): 45-75. Accessed October 25, 2020. https://www.jstor.org/stable/20163488.

Maurice, Lisa. "Saviours, Six-Packs and Sensitivity: The Hero of Greek Mythology on the Contemporary Screen." Classicum 44, no. 2 (2018): 18-28. Accessed September 16, 2020.

http://search.ebscohost.com/login.aspx?direct=true\&db=asn\&AN=137653981

$\&$ site $=$ ehost-live.

McCall, Jessica D. "Woman or Warrior? How Believable Femininity Shapes Warrior Women.” PhD diss., University of Nevada, Las Vegas, 2011, UNLV Theses, Dissertations, Professional Papers, and Capstones.

Monsacré, Hélène. The Tears of Achilles. Translated by Nicholas J. Snead. Hellenic Studies Series 75. Washington, DC: Center for Hellenic Studies, 2018. http://nrs.harvard.edu/urn-3:hul.ebook:CHS_MonsacreH.The_Tears_of_ Achilles.2018.

Penrose Jr., Walter D. "The Unwanted Gaze? Feminism and the Reception of the Amazons in Wonder Woman." Journal EuGeStA 9, no. 9 (2019): 176-224. Accessed October 3, 2020. https://eugesta-revue.univ-lille.fr/pdf/ 2019/7.Penrose_Eugesta_9_2019.pdf.

Rubarth, Scott. "Competing Constructions of Masculinity in Ancient Greece." Athens Journal of Humanities \& Arts 1, no. 1 (2014): 21-32. Accessed September 17, 2020. https://www.atiner.gr/journals/humanities/2014-1-1-2RUBARTH.pdf.

Smyrnaeus, Quintus. The Fall of Troy. Translated by A. S. Way. Loeb Classical Library Volume 19. London: William Heinemann, 1913. 
Walcot, P. "Greek Attitudes towards Women: The Mythological Evidence." Greece \& Rome 31, no. 1 (1984): 37 47. Accessed October 18, 2020. http://www.jstor.org/stable/642368.

Wood, Julia T. "Gendered Media: The Influence of Media on Views of Gender." In Gendered Lives: Communication, Gender, and Culture. Belmont, CA: Wadsworth Publishing, 1993. 